\title{
The moderating effect of self-efficacy in the relationship between subjective norms and intention to enlist in the Malaysian Army
}

\author{
Mohd Hisham bin Abdul Halim ${ }^{\underline{a}}$, Tey Lian Seng $\underline{\underline{b}}$ \\ ${ }^{a}$ Graduate School of Business, Faculty of Business and Economics, Universiti Malaya, 50603 Kuala \\ Lumpur, Malaysia. \\ ${ }^{b}$ Department of Management, Faculty of Business and Economics, Universiti Malaya, 50603 Kuala \\ Lumpur, Malaysia.
}

\begin{abstract}
Without a doubt, every Malaysian citizen, regardless of race, bears responsibility for the country's defense. However, a persistent drop in non-Bumiputra enlistment in the Malaysian Army (MA) creates a serious issue, resulting in questionable MA cohesion in protecting a multiethnic nation from a security threat. Additionally, the small number of non-Bumiputra in the MA did not reflect the country's ethnic diversity or national unity. Thus, identifying the primary predictors of non-Bumiputra to enlist in the MA will assist the MA in overcoming its ongoing struggle to lessen the organization's image as a single race organization in this multi-ethnic nation. The study hypothesized that subjective norms are a predictor of non-Bumiputra intention to enlist in MA. Data was gathered through an online survey from 384 nonBumiputra in Malaysia aged 19 to 24. The Partial Least Squares - Structural Equation Modelling (PLSSEM) method was used to validate the research model and test the hypotheses. The results show that subjective norms have a significant relationship with intention to enlist in the MA and self-efficacy significantly moderate this relationship. Theory of Reasoned Action (TRA) is extended in this study by including self-efficacy as a moderator between subjective norms and intentions. The findings provide guidelines and solutions to the MA challenge of low non-Bumiputra enlistment. Furthermore, the findings may shed light on the role of self-efficacy in predicting non-Bumiputra intention to enlist.
\end{abstract}

Keywords: Attitude, subjective norms, self-efficacy, intention, enlistment, military

\section{INTRODUCTION}

Malaysian society is divided into privileged Bumiputera (Malays and indigenous Sabah and Sarawak peoples) and non-Bumiputra (ethnic Chinese, Indians, and other non-indigenous peoples). Articles 153 and 161a of the Malaysian Federal Constitution provide non-Bumiputra with preferential access to public sector jobs including military organizations. However, only 5.5 percent of all enlisted military soldiers are non-Bumiputra due to these groups' low enlistment rate. Furthermore, there has been a significant decline in nonBumiputra interest in military enlistment, as figures reveal that from 2014 to 2019, non-Bumiputera applied for recruits to join the MA at an average rate of 1.8 percent per year, compared to Bumiputra at 98.2 percent. This incident indicates that the Malaysian Armed Forces' attempt to dispel the image of a single-race organization was merely difficult, even though the obligation to defend the country is a responsibility shared by all citizens, regardless of race or ethnic origin. Moreover, as the largest government organization, the military should promote the government's aim of fostering national unity through cooperative defense. MA must be represented by Malaysia's multi-ethnic races to position itself as the representative of all Malaysian interests and garner support from all races in times of peace and conflict. In light of the changing nature of conflict, national unity is critical for safeguarding the country from contemporary warfare (Dieu, 2020; Roosa, 2007), particularly in connection to ethnic, religious, economic, and social disparities.

Apart from the intensive recruitment drive, the Malaysian government and MA have made numerous efforts to entice non-Bumiputra to enlist

Corresponding Author: Mohd Hisham bin Abdul Halim, Faculty of Business and Economics, University of Malaya, Malaysia. 
in the military, including reviewing terms of service and salary, increasing benefits and privileges, restructuring military social support, higher learning opportunities, and medical service (MAF JD 1-0 Personnel, 2001), but only a small percentage of non-Bumiputra have enlisted. Given the increasing difficulty of fulfilling recruiting targets, studying, and assessing the factors that determine enlistment intention of non-Bumiputra to serve in the military will assist recruiters in attracting the required nonBumiputra. Extensive studies have been conducted to enrich the understanding of ethnic group enlistment in the military context (Favara, 2018; Yastrzemsky, 2016). Studies of ethnic groups in the military have indicated that different ethnic groups have distinct characteristics that influence their decision to enlist and exhibit divergent behaviour in the military (Fair \& Nawaz, 2010; Khalidi, 2001; Singh, 2017; Thibault \& Marc, 2004). As previously stated, there is a gap in the behaviour of different ethnic groups when it comes to military enlistment; nevertheless, there is scant evidence in the MA context, particularly concerning minority groups enlisting in this organisation. As such, this study conducted preliminary investigations to ascertain the internal and external elements that may affect non-Bumiputra individuals' decision to join the military. The study discovered that the significant individuals (family members, relatives, friends, and so on) who surround the decision-maker when he or she decides to enlist in MA have an impact on his or her decision to enlist in MA. Subjective norms, according to Ajzen (1991), are the perceived pressures exerted on the subject by relevant key persons. The preliminary investigation also revealed that self-efficacy is one of the elements to consider when determining an individual's intention to enlist in the MA. According to Bandura (1977), people's decisions, effort, determination, and even emotions are influenced by their beliefs about their efficacy's ability. Numerous studies have established a relationship between subjective norms, self-efficacy, and intention(Dunn, Hattie, \& Bowles, 2018; Earle et al., 2020; Fenech, Baguant, \& Ivanov, 2019; Igwe et al., 2020; Ip, Wu, Liu, \& Liang, 2017). However, the results are inconsistent and very few studies have been conducted in a military context. Thus, this study seeks to fill existing research gaps in the literature, particularly in the military context, by examining the moderating effect of self-efficacy on the relationship between subjective norms and intention to enlist in the military, in addition to examining the direct relationship between subjective norms and intention. In a nutshell, this study is essential to establish empirical evidence on the influence of subjective norms and self-efficacy on non-Bumiputra intention to enlist in the military.

\section{RESEARCH OBJECTIVE}

The objective of this study was to examine the moderating effect of self-efficacy between subjective norms and the intention of non-bumiputra to enlist in MA. The study also intended to examine the direct relationship between subjective and intention to enlist in MA.

\section{THEORETICAL BACKGROUND AND HYPOTHESES DEVELOPMENT}

The relationship between subjective norms and behavior outcomes can be better comprehended in light of TRA which is the predominant theory to define behavior with a relatively simple formula (Jones, 2020). TRA was developed by Martin Fishbein and Icek Ajzen in 1967, originated from social psychological research on the attitude and behaviour relationship. The theory was developed to better understand attitude, intention and behaviour (Fishbein \& Ajzen, 2011). TRA rests on an underlying assumption that the best predictor of behavior is intention which is determined by attitude and social perception regarding the behavior (Hale, Householder, \& Greene, 2002). According to TRA, a person's intention is a function of two basic determinants, one personal in nature and the other reflecting social influence. The first determinant, personal factor is the individual's positive or negative evaluation of performing the behavior and this factor is termed attitude toward the behavior. The second determinant of intention is the person's perception of the social pressure put on him/her to perform or not to perform the behavior in question which is termed as subjective norms.

The study focuses on the external factor which is the second determinant of TRA as a predictor of nonBumiputra intention to enlist in the MA. According to Ajzen (1991), the perception pressure was created by relevant important people surrounding the subject, consequently, this positive or negative belief will reinforce the intention towards certain behavior. Thus, the decision of non-Bumiputra to join the military is most likely influenced by the social environments around them as study shows parental recommendations of military service and communication about the enlistment process have been positively correlated with youth's propensity to enlist in the military (Gibson, Griepentrog, \& Marsh, 2007). The conceptual framework of this study is shown in Figure 1.

\section{THE RELATIONSHIP OF SUBJECTIVE NORMS AND INTENTION TO ENLIST IN MA.}


Recent studies revealed that subjective norms are significant factor to predict job search intention (Putra \& Purba, 2020; Saraih, Aris, Mutalib, Ahmad, \& Amlus, 2018; Zainal, Hairuddin, \& Kassim, 2020). Acikgoz (2019) in his research to develop an integrative model of job search and employee recruitment discovered that the intention of job seekers in the "maintaining applicant status phase" cycles is influenced by organizational attraction, employment gap, and subjective norms. The same notion was also demonstrated in studies on tourism (Park, Kim, \& Lee, 2017) and studies on multiracial groups of university students (Earle et al., 2020), in which subjective norms had a significant effect on intention behavior. However, Fenech et al. (2019) discovered that subjective norms were not a significant predictor of intention as the study was carried out in different cultural settings. In military context, study conducted on parent influence on youth in intention to enlist in military by Gibson et al. (2007) shows that parental recommendations of military service and communication about the enlistment process have been positively correlated with youth's propensity to enlist. The study supported by Yong et al. (2021) and Vinothkumar and Subramanian (2016) which both studies revealed the role of subjective norms as a significant predictor of intention to enlist in the military.

As the review of the literature demonstrates, both self-efficacy and subjective norms have been identified as primary predictors of intention to enlist in the military, when self-efficacy and subjective norms are examined independently; however, little is known about how self-efficacy interacts with subjective norms to increase intention to enlist in the military. Considering the mixed findings regarding the relationship between subjective norms and intention (Dalila, Latif, Jaafar, Aziz, \& Afthanorhan, 2020; Earle et al., 2020; Fenech et al., 2019; Park et al., 2017; Putra \& Purba, 2020; Zainal et al., 2020), it is necessary to investigate the moderating effect of self-efficacy on the relationship between subjective norms and intention of non-Bumiputra to enlist in MA. Apart from its direct effects on subjective norms and behavior outcomes, self-efficacy has been studied as a moderator of intention in business, organization behavior and networking (Ahlin, Drnovšek, \& Hisrich, 2014; Çelik, Yeloğlu, \& Y1ldırım, 2016; Igwe et al., 2020)

In this study, self-efficacy influences the intention behavior of non-Bumiputra to enlist in MA by moderating the relationship between subjective norms and intention to join MA. Self-efficacy moderates this relationship as people with high and
In the context of this research, it is expected that non-Bumiputra are influenced to enlist in MA by perceived social pressure created by "people of important" surrounding the life of non-Bumiputra due to the fact that youth tend to consult people of trust around them especially their parents to make decisions on their future career (Bright, Pryor, Wilkenfeld, \& Earl, 2005). The nature of military's work scope that are challenging, dangerous, required strong attachment and high commitment to the organization (Gade, 2017), definitely need parents' approval to enlist in the military. Additionally, strong family support ensured that military personnel received assistance in their daily life while performing their duties, which frequently needed them to be away from home (Angelis, Smith, \& Segal, 2018). Military personnel's reliance on family members for assistance during their absence, influences them to seek approval and blessing from influential persons in their daily lives prior to enlisting in MA. Based on the above arguments, the following hypothesis is posited:

H1. Subjective norms are positively related to the intention to join MA.

\section{THE MODERATING ROLE OF SELF- EFFICACY}

low self-efficacy behave differently when performing related behaviors (Chen \& Wu, 2014; Yang, 2010). According to Bandura (2010), selfefficacy refers to a strong personal belief in one's ability to initiate and complete a task; thus, in this study, non-bumiputra with a high level of selfefficacy are expected to attempt the enlistment selection to join MA. Non-Bumiputra with a high level of self-efficacy will perceive no barrier to enlisting in MA, which explains why increased selfefficacy will increase subjective norms toward intention. Based on the above arguments, the following hypothesis is posited:

H2. Self-efficacy moderates the relationship between subjective norms and the intention of nonBumiputra's to enlist in MA.

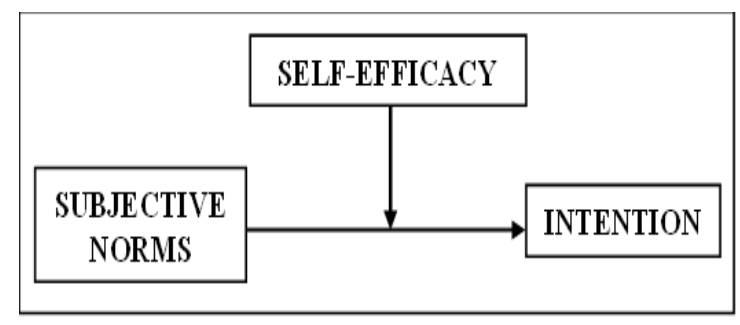

Figure 1 


\section{MEASURE}

All constructs had their measurement items adapted from the literature. Because the purpose of this study is to ascertain the relationship between subjective norms, selfefficacy, and intention to enlist in MA as perceived by non-Bumiputra, the analysis was conducted at the individual level. Subjective norms were measured using four items adapted from Fenech et al. (2019); self-efficacy was measured using six items adapted from Buch, Säfvenbom, and Boe (2015); and intention to join was measured using three items adapted from Schreurs, Derous, Hooft, Proost, and Witte (2009). Five-point Likert scale is used that stated $1=$ strongly disagree, $2=$ disagree, 3 $=$ neutral, $4=$ agree and $5=$ strongly agree. An example of these items is: "I believe that Military Service is the right job to serve my nation in a meaningful way." A convenience sampling technique was used in this crosssectional survey. To determine the sample size, Krejcie and Morgan (1970) and Uma and Roger (2016) samples sizes were used that suggested, for populations greater than 100,000 , the sample size is 384. Data were collected from non-Bumiputra across Malaysia between May 2020 and Jan 2021.

\section{RESULTS}

\section{Demographic Profile of the Respondents}

According to the demographic profile, respondents were all non-Bumiputra, aged 19 to 24 years old, with 53.4 percent of the sampled participants being men and the remaining 46.6 percent being women. The majority of respondents (78.9 percent) are single, while 15.4 percent, 5.7 percent, and 5.7 percent are married, divorced/widowed, respectively. The majority of respondents (67.4 percent) have a SPM, 9.1 percent have a STPM, only 2.9 percent have diplomas, and 20.6 percent have other levels of education. In terms of religion, 4.2 percent of respondents were Muslims, 30.5 percent were Buddhists, and 32.3 percent and 33.1 percent were Hindus and Christians, respectively. In terms of living arrangements, the majority of participants ( 88.5 percent) said they lived with the family, while 11.5 said they live alone. According to the geographical representation by state, the majority of respondents (13.4 percent) were from Kuala Lumpur, while the least was from Kelantan (1.6 percent).

\section{Data Analysis}

As the objectives of this study are related to prediction rather than parameter estimations (Hair, Risher, Sarstedt, \& Ringle, 2019), partial least squares (PLS) modeling using SmartPLS version 3.2.8 was used (Henseler, Ringle, \& Sarstedt, 2015) as the statistical tool to examine the measurement and structural model. PLSSEM also does not require an assumption of normality and survey research is frequently not normally distributed (Ringle, Sarstedt, \& Straub, 2012). As the data were collected from a single source, the issue of Common Method Bias was addressed by testing full collinearity as suggested by (Hair et al., 2019). The analysis produced a VIF of less than 5 , with subjective norms and self-efficacy having VIF values of 3.843 and 1.887 , respectively; thus, singlesource bias was not a significant issue with these data.

\section{Measurement Model}

Following the recommendations of Anderson and Gerbing (1988), the model developed was tested using a two-step approach. First, the measurement model was examined to determine the validity and reliability of the instruments, in accordance with Hair et al. (2019) and Ramayah, Hwa, Chuah, Ting, and Memon (2018). Then, the structural model was run for hypothesis testing. For the measurement model, the loadings, average variance extracted (AVE), and the composite reliability (CR) were evaluated. The values of loadings should be higher than 0.7, the AVE should be greater than 0.5 , and the CR should be higher than 0.7 (Hair et al., 2019). The fact that the loading, AVE and $\mathrm{CR}$ in this study were all attained the mentioned threshold, as shown in Table 1, indicates that the measurement items were valid and reliable. The discriminant validity was then assessed in step 2 using the HTMT criterion. HTMT values should be less than 0.85 (Kline, 2015) or 0.90 (Hair et al., 2019). As shown in Table 2, all the HTMT values were less than the stricter criterion of 0.85 . As a result, it is possible to conclude that the respondents were aware of the distinctions between the three constructs.

\section{Structural Model}

Following Hair et al. (2019) the path coefficients, the standard errors, $t$-values and $p$ values for the structural model using a 5,000sample re-sample bootstrapping procedure were reported (Ramayah et al., 2018). Table 3 shows a summary of the criteria used to test the hypotheses developed. The result shows that 
subjective norms were positively related to intention to enlist $(\beta=0.564, \mathrm{p}<.001)$, thus $\mathrm{H} 1$ was supported. $\mathrm{R}^{2}$ was 0.711 , which shows that subjective norms explained $71.1 \%$ of the variance in intention to join.

To test the moderation hypotheses, bootstrapping the indirect effect was conducted following the suggestions of Preacher and Hayes $(2004,2008)$. If the confidence interval does not straddle a 0 , then the conclusion can be made that significant moderation exists. As shown in Table 4, the confidence intervals biascorrected $95 \%$ also did not show any intervals straddling a 0 , thus confirming the findings. Therefore, H2 was also supported.

Table 1: Loading, CR and AVE

\begin{tabular}{|c|c|c|c|c|}
\hline Construct & Items & $\begin{array}{l}\text { Outer } \\
\text { Loading }\end{array}$ & CR & AVE \\
\hline \multirow{3}{*}{ Intention } & INT1 & 0.946 & \multirow{3}{*}{0.949} & \multirow{3}{*}{0.862} \\
\hline & INT2 & 0.883 & & \\
\hline & INT3 & 0.954 & & \\
\hline \multirow{6}{*}{$\begin{array}{l}\text { Self- } \\
\text { Efficacy }\end{array}$} & SE1 & 0.743 & \multirow{6}{*}{0.897} & \multirow{6}{*}{0.599} \\
\hline & SE2 & 0.863 & & \\
\hline & SE3 & 0.742 & & \\
\hline & SE4 & 0.859 & & \\
\hline & SE5 & 0.510 & & \\
\hline & SE6 & 0.866 & & \\
\hline \multirow{4}{*}{$\begin{array}{l}\text { Subjective } \\
\text { Norms }\end{array}$} & SN1 & 0.906 & \multirow{4}{*}{0.929} & \multirow{4}{*}{0.765} \\
\hline & SN2 & 0.838 & & \\
\hline & SN3 & 0.907 & & \\
\hline & SN4 & 0.845 & & \\
\hline
\end{tabular}

Table 2: HTMT Criterion

\begin{tabular}{|l|l|l|l|}
\hline CONSTRUCT & ATT & INT & SE \\
\hline Intention (Y2) & 0.609 & & \\
\hline Self-Efficacy (Y3) & 0.457 & 0.261 & \\
\hline Subjective Norms (Y4) & 0.323 & 0.747 & 0.475 \\
\hline
\end{tabular}

Table 3: Measurement Model of Direct Relationship

\begin{tabular}{|c|c|c|c|c|l|}
\hline CONS & \multirow{2}{*}{ BETA } & ST & \multicolumn{1}{|c|}{ T } & P & \multirow{2}{*}{$\mathbf{R}^{2}$} \\
\cline { 4 - 5 } TRUCT & & DEV & \multicolumn{2}{|c|}{ VALUE } & \\
\hline SN->INT & 0.564 & 0.034 & 16.677 & 0.000 & 0.711 \\
\hline
\end{tabular}

Table 4: Moderation Analysis

\begin{tabular}{|l|c|c|c|c|c|c|}
\hline \multirow{2}{*}{$\begin{array}{c}\text { CONS } \\
\text { TRUCT }\end{array}$} & \multirow{2}{*}{ BETA } & ST & \multicolumn{1}{|c|}{ T } & \multicolumn{1}{|c|}{ P } & \multicolumn{2}{|c|}{ 95\% CI } \\
\cline { 4 - 6 } & DEV & \multicolumn{2}{|c|}{ VALUE } & LB & UB \\
\hline $\begin{array}{l}\text { SN*SE- } \\
>\text { INT }\end{array}$ & 0.242 & 0.047 & 5.188 & 0.000 & 0.166 & 0.318 \\
\hline
\end{tabular}

\section{DISCUSSION}

According to the findings, subjective norms have a significant influence on the intention to enlist in the MA. Cultural setting embedded in subjective norms, the obligation to obey parents and important people who support one's daily life are also driving factors why subjective norms have an influence on non-Bumiputra intention to enlist in MA. Non-Bumiputra who enlist in MA are influenced by a sense of debt and a moral obligation to please important people in their lives. Furthermore, this behavior is influenced by the belief that parents and elderly people are wise and knowledgeable in life experience, and thus capable of providing sound advice in the intention to enlist in MA. According to Emanuel, Marsh, Boehmer, and Zucker (2005), youth enlistment in the military is frequently made after consulting with important people in their social networks. Briefly, non-Bumiputra career's influence comes in the form of knowledge, respect, moral obligation, or dependency on people in their daily lives.

In addition, subjective norms were proved to have a greater influence on high self-efficacy of non-Bumiputra since the enlistment selection procedure is considered as simple (high selfefficacy) and not as a barrier. Thus, among nonBumiputra with a high sense of self-efficacy, the only factor impacting their decision to join in MA is social pressure, not selection obstacles. Non-Bumiputra with a high sense of self-efficacy will perceive no impediment to enlisting in MA, which explains why increasing self-efficacy will raise subjective norms toward intention.

This finding is significant in developing a new strategy for enlistment advertisement that targets people of importance to nonBumiputera in order to influence the intention to enlist in the military and, as a result, increase enlistment in MA. This new strategy of targeting important people in recruitment campaigns is consistent with a study conducted by Reichert, Kim, and Fosu (2007), which found that "important people" (family 
members, relatives, and friends) have a stronger influence on military recruitment than advertising.

\section{THEORETICAL AND PRACTICAL CONTRIBUTION.}

The theoretical contribution of this study is to the body of TRA knowledge by filling the gap in understanding the effect of subjective norms in relation to intention, particularly in the military. Although much-existing literature discusses the use of TRA to explain intention behavior, there is a research deficit in the military context to better understand how subjective norms affect the intention of nonBumiputra to enlist in MA. As previous studies show that subjective norms affect intention to enlist in the military in a various ways based on ethnicity, this study specifically explains how non-Bumiputra subjective norms affect intention to enlist in MA. Most importantly, this study shows that subjective norms are a significant predictor of non-Bumiputra intention to enlist in the context of MA.

Introducing self-efficacy as a moderator also contributes to the theoretical contribution where it gives an impact on military enlistment intention. The outcome offers an insight into how self-efficacy influence subjective norms in relation to intention in military enlistment. Non-bumiputra with high self-efficacy tends to enlist in MA and non-bumiputra with low selfefficacy will avoid enlisting in MA. This study explains how self-efficacy modified the relationship between subjective norms and intention to enlist in MA.

The practical contribution is this study pathway for MA to adopt a new strategy in recruiting by targeting "people of important" surrounding potential non-Bumiputra to enlist in MA. This phenomenon is more applicable in the Asian context especially in Malaysia as the findings show that family and relatives have great influence on non-Bumiputra decision to enlist in the military. Therefore, to boost enlistment, MA should formulate dual strategy advertisement, targeting the participant directly and people around potential participants indirectly.

Non-Bumiputra applicants are deterred from joining the military due to perceived selection obstacles. Therefore, managing perceived difficulties in the MA selection process is important to increase non-Bumiputra applications to enlist in MA. MA must take action to reduce perceived hurdles in the enlisting selection procedure. MA must provide thorough and comprehensive information about selection procedures to minimize perceived problems. The advertisement for enlistment selection should not only stated qualification requirements but also an explanation, video, or link of the selection process. This will provide the potential applicant with confidence and knowledge of the selection process.

\section{RESEARCH LIMITATION AND FUTURE RESEARCH}

This research has limitations, but it leaves room for future exploration. Due to time constraints, the research solely examines the intention prediction and does not analyze the indicated predictor converted into actual conduct. In future research, longitudinal studies are preferred because outcomes may vary depending on the time period. A longitudinal strategy should be used to align the desired aim with actual behavior, allowing for deeper topic understanding. Another flaw is that this study included non-Bumiputra as a group in analysis, thus, the study's findings are not particular to any non-Bumiputra ethnicity. In future studies, non-Bumiputra ethnicities should be studied separately. Each ethnicity's impact aim differs; therefore, the finding will be more precise.

Due to the differences in job scope and services, which affect the recruitment process, this study focused exclusively on MA, rather than MN or MAF. MA members must be physically fit and have a high level of stamina to perform their duties, whereas personnel of MN or MAF rely heavily on technology to perform their duties. Individuals interested in joining the $\mathrm{MN}$ or MAF should be more tech-savvy and have a positive attitude about technology. As for MN or MAF, advised that future study focus on TAM (Technology Acceptance Model) and this model should be employed in the investigation

\section{CONCLUSION}

The study expands learning to predict intention to enlist in the MA environment by incorporating TRA and self-efficacy in a novel way. The framework model was able to garner sufficient empirical support, which complements both current research and hypotheses. This would aid the academic community in better understanding how subjective norms, and self-efficacy can all contribute to an increase in MA enlistment. Most importantly, the research's conclusion enables MA to better understand the factors that influence non- Bumiputra to join in MA and, as 
a result, develop a more effective strategy and technique for increasing non-Bumiputra enlistment in MA.

\section{REFERENCES}

[1]Acikgoz, Y. (2019). Employee Recruitment and Job Search: Towards A Multi-Level Integration. Human Resource Management Review, 29(1), 1-13. [2] Ahlin, B., Drnovšek, M., \& Hisrich, R. D. (2014). Entrepreneurs' Creativity and Firm Innovation: The Moderating Role of Entrepreneurial Self-Efficacy. Small Business Economics, 43(1), 101-117.

[3] Ajzen. (1991). The Theory of Planned Behavior. Organizational Behavior and Human Decision Processes, 50(2), 179-211.

[4] Anderson, J. C., \& Gerbing, D. W. (1988). Structural Equation Modeling in Practice: A Review and Recommended Two-Step Approach. Psychological Bulletin, 103(3), 411.

[5] Angelis, K., Smith, D. G., \& Segal, M. W. (2018). Military Families: A Comparative Perspective. In Handbook of the Sociology of the Military (pp. 341-357): Springer.

[6] Bandura, A. (1977). Self-efficacy: Toward a Unifying Theory of Behavioral Change. Psychological Review, Vol 84(2), 191-252.

[7] Bandura, A. (2010). Self-efficacy. The Corsini Encyclopedia of Psychology, 1-3.

[8] Bright, J. E., Pryor, R. G., Wilkenfeld, S., \& Earl, J. (2005). The Role of Social Context and Serendipitous Events in Career Decision Making. International journal for educational and vocational guidance, 5(1), 19-36.

[9] Buch, R., Säfvenbom, R., \& Boe, O. J. J. o. M. S. (2015). The Relationships Between Academic Self-Efficacy, Intrinsic Motivation, and Perceived Competence. 6(1), 19-35.

[10] Çelik, D. A., Yeloğlu, H. O., \& Yıldırım, O. B. (2016). The Moderating Role Of Self Efficacy on The Perceptions of Justice and Turnover Intentions. Procedia-Social Behavioral Sciences, 235, 392-402. [11] Chen, L. S.-L., \& Wu, K. I.-F. (2014). Antecedents of Intention to use CUSS System: Moderating Effects of Self-Efficacy. Service Business, 8(4), 615-634.

[12] Dalila, D., Latif, H., Jaafar, N., Aziz, I., \& Afthanorhan, A. (2020). The Mediating Effect of Personal Values on the Relationships Between Attitudes, Subjective Norms, Perceived Behavioral Control and Intention to use. Management Science Letters, 10(1), 153-162.

[13] Dieu, T. T. (2020). Ho Chi Minh's Ideology on National Unity in Vietnam's Revolution. IKAT: The Indonesian Journal of Southeast Asian Studies, 4(1), 15-23.

[14] Dunn, R., Hattie, J., \& Bowles, T. (2018). Using the Theory of Planned Behavior to Explore
Teachers' Intentions to Engage in Ongoing Teacher Professional Learning. Studies in Educational Evaluation, 59, 288-294. Retrieved from http://www.sciencedirect.com/science/article/pii/S0 191491X17303176

[15] Earle, A. M., Napper, L. E., LaBrie, J. W., Brooks-Russell, A., Smith, D. J., \& de Rutte, J. (2020). Examining Interactions Within The Theory of Planned Behavior in the Prediction of Intentions to Engage in Cannabis-Related Driving Behaviors. Journal Of American College Health, 68(4), 374380.

[16] Emanuel, S., Marsh, S., Boehmer, M., \& Zucker, A. (2005). Department of Defense Youth Poll Report and Crosstabulations Wave 8 November 2004. 232.

[17] Fair, C., \& Nawaz, S. (2010). The Changing Pakistan Army Officer Corps. Journal of Strategic Studies, 34, 63-94. doi:10.1080/01402390.2011.541765

[18] Favara, J. (2018). Good Black Soldiers: Race, Masculinity, and US Military Recruiting in the 1970s. Critical Military Studies, 1-22. doi:10.1080/23337486.2018.1463759

[19] Fenech, R., Baguant, P., \& Ivanov, D. (2019). Entrepreneurial Attitudes, Self-Efficacy, and Subjective Norms Amongst Female Emirati Entrepreneurs. Journal of Legal, Ethical and Regulatory Issues, 23, 1-11.

[20] Fishbein, M., \& Ajzen, I. (2011). Predicting and Changing Behavior: The Reasoned Action Approach: Psychology Press.

[21] Gade, P. A. (2017). Organizational Commitment in the Military: A Special Issue of Military Psychology: Psychology Press.

[22] Gibson, J. L., Griepentrog, B. K., \& Marsh, S. M. (2007). Parental Influence on Youth Propensity to Join The Military. Journal of Vocational Behavior, 70(3), 525-541. doi:10.1016/j.jvb.2007.03.002

[23] Hair, Risher, Sarstedt, \& Ringle. (2019). When To Use and How To Report The Results of PLSSEM. European business review.

[24] Hale, J. L., Householder, B. J., \& Greene, K. L. (2002). The Theory of Reasoned Action. The Persuasion Handbook: Developments in Theory and Practice, 14(2002), 259-286.

[25] Henseler, J., Ringle, C. M., \& Sarstedt, M. (2015). A New Criterion for Assessing Discriminant Validity in Variance-Based Structural Equation Modeling. Journal of the academy of marketing science, 43(1), 115-135.

[26] Igwe, A., Ogbo, A., Agbaeze, E., Abugu, J., Ezenwakwelu, C., \& Okwo, H. (2020). SelfEfficacy and Subjective Norms as Moderators in the Networking Competence-Social Entrepreneurial Intentions Link. SAGE Open, 10(3), 2158244020934878.

[27] Ip, C. Y., Wu, S.-C., Liu, H.-C., \& Liang, C. (2017). Revisiting the Antecedents of Social 
Entrepreneurial Intentions in Hong Kong. International Journal of Educational Psychology, 6(3), 301-323.

[28] Jones, A. H. G. (2020). Using The Theory of Reasoned Action to Examine Faculty Intentions to use Social Networking in Distance Learning Courses. University of Alabama Libraries,

[29] Khalidi, O. (2001). Ethnic Group Recruitment in the Indian Army: The Contrasting Cases of Sikhs, Muslims, Gurkhas and Others. Pacific Affairs, 74, 529-552. doi: $10.2307 / 3557805$

[30] Kline, R. B. (2015). Principles and Practice of Structural Equation Modeling: Guilford Publications.

[31] Krejcie, R. V., \& Morgan, D. W. (1970). Determining Sample Size for Research Activities. 30(3), 607-610. doi:10.1177/001316447003000308 [32] MAF JD 1-0 Personnel. (2001). Kuala Lumpur: Malaysian Armed Forces Headquarters

[33] Park, Kim, H.-b., \& Lee, K.-W. (2017). Perceptions of Determinants of Job Selection in The Hospitality and Tourism Industry: The Case of Korean University Students. Journal of Human Resources in Hospitality \& Tourism, 16(4), 422444. doi:10.1080/15332845.2017.1266874

[34] Putra, I. H., \& Purba, D. E. (2020). Effects of Internship Satisfaction, Subjective Norms, and SelfEfficacy on Student Intern's Job Application Intention. Psychological Research on Urban Society, 3(2), 87-96.

[35] Ramayah, T., Hwa, C., Chuah, F., Ting, H., \& Memon, M. (2018). Partial Least Squares Structural Equation Modeling (PLS-SEM) using SmartPLS 3.0: An Updated and Practical Guide to Statistical Analysis.

[36] Reichert, T., Kim, J., \& Fosu, I. (2007). Assessing the Efficacy of Armed-Forces Recruitment Advertising: A Reasoned-Action Approach. Journal of Promotion Management, 13(34), 399-412. doi:10.1080/10496490802307085

[37] Ringle, C. M., Sarstedt, M., \& Straub, D. W. (2012). Editor's Comments: A Critical Look at the use of PLS-SEM In" MIS Quarterly". MIS quarterly, iii-xiv.

[38] Roosa, J. (2007). Finalising the Nation: The Indonesian Military as the Guarantor of National Unity. Asia Pacific Viewpoint, 48(1), 99-111.

[39] Saraih, U. N., Aris, A. Z. Z., Mutalib, S. A., Ahmad, T. S. T., \& Amlus, M. H. (2018). Examining the Relationships Between Attitude Towards Behaviour, Subjective Norms and Entrepreneurial Intention Among Engineering Students. Paper presented at the MATEC Web of Conferences.

[40] Schreurs, B., Derous, E., Hooft, E., Proost, K., \& Witte, K. (2009). Predicting Applicants' Job Pursuit Behavior from their Selection Expectations: The Mediating Role of the Theory of Planned Behavior. Journal of Organizational Behavior, 30, 761-783. doi:10.1002/job.570

[41] Singh, M. (2017). Soldiers' Recruitment in
South Asia:An Empirical Case Study of the Propensity of Indian Gujarati Youth to Enlist. Armed Forces and Society, 43(4), 632-653. doi:10.1177/0095327x 16667085

[42] Thibault, \& Marc. (2004). A Multivariate Analysis of United States Coast Guard Enlistment Propensity. George Mason University,

[43] Uma, S., \& Roger, B. (2016). Research Method for Business- A skill Building Approach. New York: Wiley.

[44] Vinothkumar, M., \& Subramanian, S. (2016). Self-Efficacy, Attitude and Subjective Norms as Predictors of Youth's Intention to Enlist in Defence Services. Journal of the Indian Academy of Applied Psychology, 42(2), 310.

[45] Yang, K. (2010). The Effects of Technology Self-Efficacy and Innovativeness on Consumer Mobile Data Service Adoption Between American and Korean Consumers. Journal of International Consumer Marketing, 22(2), 117-127.

[46] Yastrzemsky, J. R. (2016). The Propensity to Serve in The Armed Forces: An Examination into the Factors Associated with Military Propensity During The Post-9/11 Era. (Ph.D.). University of Maryland, College Park, Ann Arbor. Retrieved from http://ezproxy.um.edu.my:2048/login?url=https://se arch.proquest.com/docview/1861722131?accountid $=28930$ ProQuest Dissertations \& Theses Global Database. (10193210)

[47] Yong, W. K., Husin, M. M., Liew, K. J., Sockanathan, S., Ismail, N., Rosly, M. R., . . . Ahmad, F. S. (2021). Identifying the Key Beliefs of Private University Students Towards Joining The Malaysian Armed Forces. International Journal of Business Continuity and Risk Management, 11(2-3), 142-155.

[48] Zainal, N. Z., Hairuddin, H., \& Kassim, E. S. (2020). Psychological Determinants of Job Search Intention Among Fresh Graduates for the Supply of Labour Force in The Digital Era. Asia Proceedings of Social Sciences, 6(3), 204-210. 